\title{
An Evaluation of Biofield Treatment on Susceptibility Pattern of Multidrug Resistant Stenotrophomonas maltophilia: An Emerging Global Opportunistic Pathogen
}

\author{
Mahendra Kumar Trivedi ${ }^{1}$, Shrikant Patil ${ }^{1}$, Harish Shettigar ${ }^{1}$, Mayank Gangwar ${ }^{2}$ and Snehasis Jana ${ }^{2 \star}$ \\ ${ }^{1}$ Trivedi Global Inc., 10624 S Eastern Avenue Suite A-969, Henderson, NV 89052, USA \\ ${ }^{2}$ Trivedi Science Research Laboratory Pvt. Ltd., Hall-A, Chinar Mega Mall, Chinar Fortune City, Hoshangabad Rd., Bhopal-462026 Madhya Pradesh, India \\ "Corresponding author: Snehasis Jana, Trivedi Science Research Laboratory Pvt. Ltd., Hall-A, Chinar Mega Mall, Chinar Fortune City, Hoshangabad Rd., \\ Bhopal-462026, Madhya Pradesh, India, Tel: +91-755-6660006; E-mail: publication@trivedisrl.com
}

Received date: June 17, 2015; Accepted date: July 17, 2015; Published date: July 24, 2015

Copyright: () 2015 Trivedi MK, et al. This is an open-access article distributed under the terms of the Creative Commons Attribution License, which permits unrestricted use, distribution, and reproduction in any medium, provided the original author and source are credited.

\begin{abstract}
Stenotrophomonas maltophilia (S. maltophilia) is a Gram-negative bacillus, an opportunistic pathogen, particularly among nosocomial infections. Multi-drug resistant strains are associated with very high rate of morbidity and mortality in severely immunocompromised patients. Present study was designed to evaluate the effect of biofield treatment against multidrug resistant $S$. maltophilia. Clinical sample of $S$. maltophilia was collected and divided into two groups i.e. control and biofield treated which were analyzed after 10 days with respect to control. The following parameters viz. susceptibility pattern, minimum inhibitory concentration (MIC), biochemical studies and biotype number of both control and treated samples were measured by MicroScan Walk-Away ${ }^{\circledR}$ system. The results showed an overall change of $37.5 \%$ in susceptibility pattern and $39.4 \%$ in biochemical study while $33.3 \%$ changes in MIC values of tested antimicrobials after biofield treatment. Further, the treated group of $S$. maltophilia has also shown a significant change in biochemical reactions followed by its biotype number as compared to control group. Biochemical reactions of treated group showed negative reaction to acetamide and positive reactions to colistin, glucose, adonitol, melibiose, arabinose, nitrate, oxidation-fermentation, raffinose, rhaminose, sorbitol, sucrose, and Voges-Proskauer as compared with control. The biofield treatment showed an alteration in MIC values of amikacin, amoxicillin/K-clavulanate, chloramphenicol, gatifloxacin, levofloxacin, moxifloxacin, ceftazidime, cefotetan, ticarcillin/K-clavulanate, trimethoprim/sulfamethoxazole. Altogether, data suggest that biofield treatment has significant effect to alter the sensitivity pattern of antimicrobials and biotype number against multidrug resistant strain of S. maltophilia.
\end{abstract}

Keywords: Stenotrophomonas maltophilia; Multidrug resistant; Antimicrobial susceptibility; Biofield treatment; Biochemical reactions; Biotyping

\section{Introduction}

During the last few decades, due to the continuous deployment of antimicrobial drugs, incidence of microbial resistance has increased leads to generating multi-drug-resistance (MDR) organisms (MDROs). MDR strains and its related infections have been increased suddenly, which leads to ineffective treatment and risk of spreading infections. Although, MDR development is a natural phenomenon, but extensive rise in the number of immunocompromised patients leads to examine the possible source and elucidate the molecular mechanism of organism during infection [1,2]. Serious threats in front of researchers are the resistant pattern of Gram negative pathogens for almost all available antimicrobials. Reason being the MDR pumps, plasmids carrying resistance genes and involvement of different transfer mechanisms of resistance [3]. S. maltophilia is an aerobic, nonfermentative and Gram-negative bacterium regarded as global emerging MDRO in hospitalized or immunocompromised patients [4]. S. maltophilia is not highly virulent pathogen, but it has the ability to colonize in human respiratory tract in hospitals responsible for crude mortality rates i.e. 14\%-69\% with bacteremia [5,6]. Currently, no such alternative approaches for altering the sensitivity pattern of antimicrobials are available against MDROs, biofield treatment may be a new approach to alter the susceptibility pattern of $S$. maltophilia.

Now a days, acceptance and applications of complementary and alternative therapies are at global level. Many alternative remedies including biofield energy treatment (such as Qi gong, and Tai chi) have recently found their way into the medical mainstream and is widely accepted by most of the healthcare professionals [7]. Alternative remedies trace the root cause of diseases or impairment. Recently, Lucchetti et al. reported the effective impact of spiritual healing on inhibiting the growth of bacterial cultures [8], suggests that biofield treatment could be a new and effective treatment approach. Still, this treatment is not much explored in mainstream medicine and research; it should continue to be experimentally examined in different biological fields.

Bio-electromagnetism is a branch which helps to detect the electric, electromagnetic, and magnetic phenomena originates in biological tissues. According to universal principles of Maxwell's equations and principle of reciprocity, it defines electromagnetic connections related to human biofield [9]. Thus, the cumulative effect of bio-magnetic field and electric field that surrounds the human body is defined as biofield. The energy associated with this field is considered as biofield energy and it can be monitored by using techniques such as electromyography (EMG), electrocardiography (ECG) and electroencephalogram (EEG) [10]. However, the energy can exists in 
Citation: $\quad$ Trivedi MK, Patil S, Shettigar H, Gangwar M, Jana S (2015) An Evaluation of Biofield Treatment on Susceptibility Pattern of Multidrug Resistant Stenotrophomonas maltophilia: An Emerging Global Opportunistic Pathogen. Clin Microbiol 4: 211. doi: $10.4172 / 2327-5073.1000211$

Page 2 of 5

several forms such as kinetic, potential, electrical, magnetic, and nuclear. Similarly, the human nervous system consists of the energy and chemical information in the form of electrical signals. Mr. Mahendra Trivedi's biofield treatment has considered a significant impact and reported in different fields like growth and yield of different crops in agriculture [11,12], changed atomic and crystalline characteristics of metals $[13,14]$ and in microbiology, altered the sensitivity and antimicrobial pattern of pathogenic microbes [15-17].

There are very few reports on biofield treatment against sensitivity pattern of MDROs. The present study was undertaken to evaluate the impact of biofield treatment on MDR strain of $S$. maltophilia. The change in antimicrobial susceptibility pattern, MIC, biochemical reactions, and biotype number were studied and compared with control group.

\section{Materials and Methods}

\section{Test micro-organism and experimental design}

Clinical sample of MDR strain of $S$. maltophilia was collected from stored stock cultures in Microbiology Lab, Hinduja Hospital, Mumbai and stored with proper storage conditions until further use. Experimental setup was designed and MDR strain was divided in two groups i.e. control and treatment. Treatment group was subjected to Mr. Trivedi's biofield energy and analyzed on day 10 with respect to control. After biofield treatment, following parameters like antimicrobial susceptibility, MIC values, biochemical reactions and biotype number were measured by MicroScan Walk-Away" (Dade Behring Inc., USA) using Negative Break Point Combo (NBPC 30) panel with respect to control groups.

\section{Evaluation of antimicrobial susceptibility assay}

Antimicrobial susceptibility pattern of $S$. maltophilia was studied using MicroScan Walk-Away NBPC30 as per manufacturer's instructions. The qualitative antimicrobial susceptibility pattern (S: Susceptible, I: Intermediate, and R: Resistant) and minimum inhibitory concentration (MIC) values were determined by observing the lowest antimicrobial concentration showing growth inhibition [18]. The antimicrobials used in the susceptibility assay and MIC calculations viz. amikacin, amox/K-clavulanate, amp/sulbactum, ampicillin, aztreonam, cefazolin, cefepime, cefotetan, cefotaxime, cefoxitin, ceftazidime, ceftriaxone, cefuroxime, cephalothin, chloramphenicol, ciprofloxacin, extended spectrum $\beta$-lactamase (ESBL), gentamicin, gatifloxacin, imipenem, levofloxacin, meropenem, moxifloxacin, nitrofurantoin, norfloxacin, tetracycline, ticarcillin/Kclavulanate, tobramycin, and trimethoprim/sulfamethoxazole.

\section{Biochemical study}

The biochemical reactions of control and treated $S$. maltophilia were determined by MicroScan Walk-Away system in both control and treated groups [18].

\section{Identification by biotype number}

The biotype numbers of $S$. maltophilia control and treated sample were determined by MicroScan Walk-Away processed panel data report with the help of biochemical reaction data [18].

\section{Results}

\section{Antimicrobial susceptibility}

Results of antimicrobial sensitivity pattern and MIC are summarized in Tables 1 and 2, respectively. The biofield treatment on MDR strain of $S$. maltophilia showed a significant change in sensitivity pattern from $\mathrm{I} \rightarrow \mathrm{R}$ with different MIC values of tested antimicrobials such as ceftazidime, levofloxacin, and ticarcillin/K-clavulanate. Amikacin sensitivity converted from $\mathrm{R} \rightarrow \mathrm{I}$ with altered MIC value (i.e. $32 \mu \mathrm{g} / \mathrm{ml}$ ), trimethoprim/sulfamethoxazole changed from $S \rightarrow R$, and chloramphenicol converted from $\mathrm{S} \rightarrow \mathrm{I}$ with altered MIC value (i.e. 16 $\mu \mathrm{g} / \mathrm{ml})$. Amoxicillin/clavulanate was reported with altered MIC value that was greater than $16 / 8 \mu \mathrm{g} / \mathrm{ml}$ as compared to control. Rest of the tested antimicrobials did not showed any change in sensitivity pattern and MIC value.

\begin{tabular}{|c|c|c|c|}
\hline S. No & Antimicrobial & Control & Treated \\
\hline 1 & Amikacin & $\mathrm{R}$ & I \\
\hline 2 & Aztreonam & $\mathrm{R}$ & $\mathrm{R}$ \\
\hline 3 & Cefepime & $\mathrm{R}$ & $\mathrm{R}$ \\
\hline 4 & Cefotaxime & $\mathrm{R}$ & $\mathrm{R}$ \\
\hline 5 & Ceftazidime & 1 & $\mathrm{R}$ \\
\hline 6 & Ceftriaxone & $\mathrm{R}$ & $\mathrm{R}$ \\
\hline 7 & Chloramphenicol & S & 1 \\
\hline 8 & Ciprofloxacin & $\mathrm{R}$ & $\mathrm{R}$ \\
\hline 9 & Gentamicin & $\mathrm{R}$ & $\mathrm{R}$ \\
\hline 10 & Imipenem & $\mathrm{R}$ & $\mathrm{R}$ \\
\hline 11 & Levofloxacin & I & $\mathrm{R}$ \\
\hline 12 & Meropenem & $\mathrm{R}$ & $\mathrm{R}$ \\
\hline 13 & Tetracycline & $\mathrm{R}$ & $\mathrm{R}$ \\
\hline 14 & Ticarcillin/K-Clavulanate & I & $\mathrm{R}$ \\
\hline 15 & Tobramycin & $\mathrm{R}$ & $\mathrm{R}$ \\
\hline 16 & Trimethoprim/Sulfamethoxazole & S & $\mathrm{R}$ \\
\hline
\end{tabular}

R: Resistant; I: Intermediate; S: Susceptible

Table 1: The result of antimicrobial sensitivity assay of Stenotrophomonas maltophilia in control and biofield treated group.

\begin{tabular}{|c|c|c|c|}
\hline S. No. & Antimicrobial & Control & Treated \\
\hline 1 & Amikacin & $>32$ & 32 \\
\hline 2 & Amox/K-clavulanate & $16 / 8$ & $>16 / 8$ \\
\hline 3 & Amp/Sulbactum & $>16 / 8$ & $>16 / 8$ \\
\hline 4 & Ampicillin & $>16$ & $>16$ \\
\hline 5 & Aztreonam & $>16$ & $>16$ \\
\hline 6 & Cefazolin & $>16$ & $>16$ \\
\hline
\end{tabular}


Citation: $\quad$ Trivedi MK, Patil S, Shettigar H, Gangwar M, Jana S (2015) An Evaluation of Biofield Treatment on Susceptibility Pattern of Multidrug Resistant Stenotrophomonas maltophilia: An Emerging Global Opportunistic Pathogen. Clin Microbiol 4: 211. doi: $10.4172 / 2327-5073.1000211$

Page 3 of 5

\begin{tabular}{|c|c|c|c|}
\hline 7 & Cefepime & $>16$ & $>16$ \\
\hline 8 & Cefotaxime & $>32$ & $>32$ \\
\hline 9 & Cefotetan & $\leq 16$ & 32 \\
\hline 10 & Cefoxitin & $>16$ & $>16$ \\
\hline 11 & Ceftazidime & 16 & $>16$ \\
\hline 12 & Ceftriaxone & $>32$ & $>32$ \\
\hline 13 & Cefuroxime & $>16$ & $>16$ \\
\hline 14 & Cephalothin & $>16$ & $>16$ \\
\hline 15 & Chloramphenicol & $\leq 8$ & 16 \\
\hline 16 & Ciprofloxacin & $>2$ & $>2$ \\
\hline 17 & ESBL-a Scrn & $>4$ & $>4$ \\
\hline 18 & ESBL-b Scrn & $>1$ & $>1$ \\
\hline 19 & Gatifloxacin & 4 & $>4$ \\
\hline 20 & Gentamicin & $>8$ & $>8$ \\
\hline 21 & Imipenem & $>8$ & $>8$ \\
\hline 22 & Levofloxacin & 4 & $>4$ \\
\hline 23 & Meropenem & $>8$ & $>8$ \\
\hline 24 & Moxifloxacin & $\leq 2$ & $>4$ \\
\hline 25 & Nitrofurantoin & $>64$ & $>64$ \\
\hline 26 & Norfloxacin & $>8$ & $>8$ \\
\hline 27 & Tetracycline & $>8$ & $>8$ \\
\hline 28 & Ticarcillin/K-clavulanate & 64 & $>64$ \\
\hline 29 & Tobramycin & $>8$ & $>8$ \\
\hline 30 & Trimethoprim/Sulfamethoxazole & $\leq 2 / 38$ & $>2 / 38$ \\
\hline
\end{tabular}

Table 2: Minimum inhibitory concentration of antimicrobials in control and treated groups after biofield treatment on Stenotrophomonas maltophilia.

Overall, results showed a change of $37.5 \%$ in susceptibility pattern and $33.3 \%$ in MIC values of tested antimicrobials. All these changes were observed after 10 days of biofield treatment as compared to control group.

\section{Biochemical reaction}

Table 3 summarizes the biochemical reactions denoted with codes in control and biofield treated group on day 10. Results showed an alteration of $39.4 \%$ in biochemical study likewise in acetamide (i.e. from $(+)$ positive to $(-)$ negative reaction) while reverse responses (i.e. from (-) negative to $(+)$ positive reaction) in adonitol, arabinose, colistin, glucose, melibiose, nitrate, oxidation-fermentation, raffinose, rhaminose, sorbitol, sucrose, and Voges-Proskauer were reported after biofield treatment as compared with control.

\begin{tabular}{|c|c|c|c|c|}
\hline S. No. & Code & Biochemical & Control & Treated \\
\hline 1 & ACE & Acetamide & + & - \\
\hline 2 & ADO & Adonitol & - & + \\
\hline 3 & ARA & Arabinose & - & + \\
\hline 4 & ARG & Arginine & - & - \\
\hline 5 & CET & Cetrimide & - & - \\
\hline 6 & CF8 & Cephalothin & + & + \\
\hline 7 & CIT & Citrate & + & + \\
\hline 8 & CL4 & Colistin & - & + \\
\hline 9 & ESC & Esculin hydrolysis & + & + \\
\hline 10 & FD64 & Nitrofurantoin & + & + \\
\hline 11 & GLU & Glucose & - & + \\
\hline 12 & $\mathrm{H} 2 \mathrm{~S}$ & Hydrogen sulfide & - & - \\
\hline 13 & IND & Indole & - & - \\
\hline 14 & INO & Inositol & - & - \\
\hline 15 & K4 & Kanamycin & + & + \\
\hline 16 & LYS & Lysine & + & + \\
\hline 17 & MAL & Malonate & + & + \\
\hline 18 & MEL & Melibiose & - & + \\
\hline 19 & NIT & Nitrate & - & + \\
\hline 20 & OF/G & Oxidation-Fermentation & - & + \\
\hline 21 & ONPG & Galactosidase & - & - \\
\hline 22 & ORN & Ornithine & - & - \\
\hline 23 & OXI & Oxidase & - & - \\
\hline 24 & P4 & Penicillin & + & + \\
\hline 25 & RAF & Raffinose & - & + \\
\hline 26 & RHA & Rhamnose & - & + \\
\hline 27 & SOR & Sorbitol & - & + \\
\hline 28 & SUC & Sucrose & - & + \\
\hline 29 & TAR & Tartarate & - & - \\
\hline 30 & TDA & Tryptophan Deaminase & - & - \\
\hline 31 & TO4 & Tobramycin & + & + \\
\hline 32 & URE & Urea & - & - \\
\hline 33 & VP & Voges-Proskauer & - & + \\
\hline
\end{tabular}

Table 3: Effect of biofield treatment on biochemical reactions of Stenotrophomonas maltophilia. 
Citation: $\quad$ Trivedi MK, Patil S, Shettigar H, Gangwar M, Jana S (2015) An Evaluation of Biofield Treatment on Susceptibility Pattern of Multidrug Resistant Stenotrophomonas maltophilia: An Emerging Global Opportunistic Pathogen. Clin Microbiol 4: 211. doi: $10.4172 / 2327-5073.1000211$

Page 4 of 5

\section{Organism identification by biotype number}

Based on the biochemical results, change in biotype number was observed in biofield treated group at day 10 of $S$. maltophilia with respect to control. After alteration in biotype number the organism was identified as Enterobacter aerogenes (Table 4).

\begin{tabular}{|c|c|c|}
\hline Feature & Control & Treated \\
\hline Biotype & 04262330 & 77304366 \\
\hline Organism Identification Name & Stenotrophomonas maltophilia & Enterobacter aerogenes \\
\hline
\end{tabular}

Table 4: Effect of biofield treatment on S. maltophilia to distinguishing feature of the genotype.

\section{Discussion}

Biofield treatment was reported as an alternative therapy and termed as frontier medicine in different fields [19]. This experimental study was designed to demonstrate the effect on susceptibility pattern, biochemical reaction and biotype number after biofield treatment in MDR strain of $S$. maltophilia.

The emergence of MDR of $S$. maltophilia harbored a global health problem and an emerging Gram-negative MDROs commonly associated with severe systemic and respiratory infections in human. MDR is an unavoidable natural phenomenon which compels continuous discovery of newer drugs causing serious public health problems. Various mechanisms involved in MDR include alteration in the cell membrane composition of microorganism resulting in decreased permeability and uptake of drugs into the cell [20], overexpression of drug target enzymes or altered the drug target through mutation [21], and drug efflux pumps remains the predominant mechanism in MDRO [22]. Now a days, $S$. maltophilia acquires resistance against broad range of antimicrobials, including trimethoprim/sulfamethoxazole, $\beta$-lactam antibiotics, macrolides, cephalosporins, fluoroquinolones, aminoglycosides, carbapenems, chloramphenicol, tetracyclines, and polymyxins. Due to this, use of combination therapy is suggested rather than monotherapy against $S$. maltophilia infection. Amikacin is the best drug of choice in combination with trimethoprim/sulfamethoxazole due to its high activity and favorite outcomes [23]. Our results showed a change in sensitivity pattern of amikacin from resistant to intermediate $(\mathrm{R} \rightarrow \mathrm{I})$ along with changes in sensitivity of trimethoprim/sulfamethoxazole (i.e. $S \rightarrow R$ ) and chloramphenicol (i.e. $S \rightarrow I$ ). Apart from this, sensitivity pattern of ceftazidime levofloxacin, and ticarcillin/k-clavulanate also changed from $I \rightarrow R$. Above antimicrobials are the newer combination strategy against treatment of $S$. maltophilia infection [24,25]. These results suggest that biofield treatment possibly made some alterations either in some enzymatic pathways of microorganism or a change at genetic level, which leads to alter the phenotypic features of $S$. maltophilia like sensitivity pattern and MIC values in biofield treated group.

S. maltophilia has the ability to survive in nutrient-poor aqueous medium or environment. Typical biochemical reactions of $S$. maltophilia showed negative responses in case of oxidase, indole, arabinose, rhamnose, hydrogen sulfide, and Voges-Proskauer [26]. In this study, similar pattern was shown in control group in tested microbe, but biofield treatment has changed the biochemical reaction pattern from negative to positive reaction in case of adonitol, arabinose, colistin, glucose, melibiose, nitrate, oxidation-fermentation, raffinose, rhaminose, sorbitol, sucrose, and Voges-Proskauer as compared with control. Biotyping was performed using an automated system and found a significant changed in biotype number (04262330) in treated group on day 10, and organism identified as Enterobacter aerogenes (77304366) after biofield treatment.

A major challenge for research in microbiology and MDROs is its ability to adapt to the local environment and alter the antimicrobial activities. Due to MDR infections, development of new treatment approach is required. Biofield treatment as an alternate and complementary medicine, increasingly used in biomedical health care system [27]. However, National Center for Complementary and Alternative Medicine/National Institute of Health (NCCAM/NIH), now defined biofield therapies in subcategory of energy therapies as one of the five complementary medicine domains [28]. Mr. Trivedi's biofield treatments in pathogenic microbes were extensively studied and had shown significant alteration in the antimicrobial sensitivity pattern, biochemical reactions, and biotype number [15-17]. Biofield treatment might be responsible to do alteration in microorganism at genetic level and/or enzymatic level, which may act on receptor protein. While altering receptor protein, ligand-receptor/protein interactions may also alter that could lead to show different phenotypic characteristics. Hence a cascade of intra-cellular signals may be initiated, accelerated or inhibited [29]. These results indicate that biofield treatment has altered the sensitivity pattern of antimicrobials which leads to alter the phenotypic features of $S$. maltophilia. Considering that there are no side effects in the biofield treatment, as experimentally proofed in other reports of cancer model, stress management, and in healing process by biofield energy. The study results indicate that biofield treatment significantly altered the sensitivity pattern and biotype number of $S$. maltophilia.

\section{Conclusion}

Present study concludes there was a significant impact of biofield treatment of susceptibility pattern of antimicrobials, biochemical reactions, and biotype number of MDR strain of $S$. maltophilia. On the basis of above results, future studies can be designed with respect to genotypic identification of new microorganism, or biofield treatment modality could be further evaluated on the basis of different distance and time interval against pathogenic microbes, viruses, parasites, cell lines etc. Biofield treatment could be applied in future to alter the sensitivity of antimicrobials, which may be useful, if resistant profile is changed in to sensitive against antimicrobials used for multidrug resistant organisms.

\section{Conflict of Interest}

The authors declare that they have no competing interest. 
Citation: $\quad$ Trivedi MK, Patil S, Shettigar H, Gangwar M, Jana S (2015) An Evaluation of Biofield Treatment on Susceptibility Pattern of Multidrug Resistant Stenotrophomonas maltophilia: An Emerging Global Opportunistic Pathogen. Clin Microbiol 4: 211. doi: $10.4172 / 2327-5073.1000211$

Page 5 of 5

\section{Acknowledgement}

Authors gratefully acknowledged the whole team of PD Hinduja National Hospital and MRC, Mumbai, Microbiology Lab for their support.

\section{References}

1. Singh V (2013) Antimicrobial resistance. In: Microbial pathogens and strategies for combating them: science, technology and education. Formatex Research Center, India.

2. Popęda M, Płuciennik E, Bednarek AK (2014) [Proteins in cancer multidrug resistance]. Postepy Hig Med Dosw (Online) 68: 616-632.

3. Livermore DM (2004) The need for new antibiotics. Clin Microbiol Infect 10 Suppl 4: 1-9.

4. Jumaa PA, Sonnevend A, Pàl T, El Hag M, Amith R, et al. (2006) The molecular epidemiology of Stenotrophomonas maltophilia bacteraemia in a tertiary referral hospital in the United Arab Emirates 2000-2004. Ann Clin Microbiol Antimicrob 5: 32

5. Jang TN, Wang FD, Wang LS, Liu CY, Liu IM (1992) Xanthomonas maltophilia bacteremia: an analysis of 32 cases. J Formos Med Assoc 91: 1170-1176.

6. Victor MA, Arpi M, Bruun B, Jønsson V, Hansen MM (1994) Xanthomonas maltophilia bacteremia in immunocompromised hematological patients. Scand J Infect Dis 26: 163-170.

7. Clarke TC, Black LI, Stussman BJ, Barnes PM, Nahin RL (2015) Trends in the use of complementary health approaches among adults: United States, 2002-2012. Natl Health Stat Report : 1-16.

8. Lucchetti G, de Oliveira RF, Gonçalves JP, Ueda SM, Mimica LM, et al. (2013) Effect of Spiritist "passe" (Spiritual healing) on growth of bacterial cultures. Complement Ther Med 21: 627-632.

9. Maxwell J (1865) A dynamical theory of the electromagnetic field. Phil Trans R Soc Lond 155: 459-512.

10. Movaffaghi Z, Farsi M (2009) Biofield therapies: biophysical basis and biological regulations? Complement Ther Clin Pract 15: 35-37.

11. Patil SA, Nayak GB, Barve SS, Tembe RP, Khan RR (2012) Impact of biofield treatment on growth and anatomical characteristics of pogostemon cablin (Benth.). Biotechnology 11: 154-162.

12. Altekar N, Nayak G (2015) Effect of biofield treatment on plant growth and adaptation. J Environ Health Sci 1: 1-9.

13. Dabhade VV, Tallapragada RR, Trivedi MK (2009) Effect of externa energy on atomic, crystalline and powder characteristics of antimony and bismuth powders. Bull Mat Sci 32: 471-479.

14. Trivedi MK, Patil S, Tallapragada RM (2012) Thought intervention through biofield changing metal powder characteristics experiments on powder characterisation at a PM Plant. Lecture Notes in Electrical Engineering 173: 247-252.

15. Trivedi MK, Patil S (2008) Impact of an external energy on Staphylococcus epidermis [ATCC-13518] in relation to antibiotic susceptibility and biochemical reactions-an experimental study. J Accord Integr Med 4: 230-235.

16. Trivedi MK, Patil S (2008) Impact of an external energy on Yersinia enterocolitica [ATCC-23715] in relation to antibiotic susceptibility and biochemical reactions: an experimental study. Internet J Alternat Med 6: 13.

17. Trivedi MK, Bhardwaj Y, Patil S, Shettigar H, Bulbule A (2009) Impact of an external energy on Enterococcus faecalis [ATCC-51299] in relation to antibiotic susceptibility and biochemical reactions-an experimental study. J Accord Integr Med 5: 119-130.

18. Fader RC, Weaver E, Fossett R, Toyras M, Vanderlaan J, et al. (2013) Multilaboratory study of the biomic automated well-reading instrument versus MicroScan WalkAway for reading MicroScan antimicrobial Susceptibility and identification panels. J Clin Microbiol 51: 1548-1554.

19. Krucoff MW, Crater SW, Gallup D, Blankenship JC, Cuffe M, et al. (2005) Music, imagery, touch, and prayer as adjuncts to interventional cardiac care: the monitoring and actualisation of noetic trainings (MANTRA) II randomized study. Lancet 366: 211-217.

20. Tenover FC (2006) Mechanisms of antimicrobial resistance in bacteria. Am J Med 119: S3-10.

21. He X, Li S, Kaminskyj SG (2013) Using Aspergillus nidulans to identify antifungal drug resistance mutations. Eukaryot Cell 13: 288-294.

22. Alekshun MN, Levy SB (2007) Molecular mechanisms of antibacterial multidrug resistance. Cell 128: 1037-1050.

23. Entenza JM, Moreillon P (2009) Tigecycline in combination with other antimicrobials: a review of in vitro, animal and case report studies. Int J Antimicrob Agents 34: e1-e9.

24. Maisetta G, Mangoni ML, Esin S, Pichierri G, Capria AL, et al. (2009) In vitro bactericidal activity of the $\mathrm{N}$-terminal fragment of the frog peptide esculentin-1b (Esc 1-18) in combination with conventional antibiotics against Stenotrophomonas maltophilia. Peptides 30: 1622-1626.

25. Zelenitsky SA, Iacovides H, Ariano RE, Harding GK (2005) Antibiotic combinations significantly more active than monotherapy in an in vitro infection model of Stenotrophomonas maltophilia. Diagn Microbiol Infect Dis 51: 39-43.

26. Carmody LA, Spilker T, LiPuma JJ (2011) Reassessment of Stenotrophomonas maltophilia phenotype. J Clin Microbiol 49: 1101-1103.

27. Turner JG, Clark AJ, Gauthier DK, Williams M (1998) The effect of therapeutic touch on pain and anxiety in burn patients. J Adv Nurs 28: $10-20$

28. Koithan M (2009) Introducing Complementary and Alternative Therapies. J Nurse Pract 5: 18-20.

29. Hintz KJ, Yount GL, Kadar I, Schwartz G, Hammerschlag R, et al. (2003) Bioenergy definitions and research guidelines. Altern Ther Health Med 9: A13-30. 